\title{
Surfaces
}

BIODEGRADABILITY: FLOATING ON THE SURFACE OF CULTURE

\section{Lisa Zucker}

Volume 2, 1992

ACTES DU COLLOQUE « REPENSER LA CULTURE » ACTS OF THE CONFERENCE "RETHINKING CULTURE"

URI : https://id.erudit.org/iderudit/1065234ar

DOI : https://doi.org/10.7202/1065234ar

Aller au sommaire du numéro

Éditeur(s)

Les Presses de l’Université de Montréal

ISSN

1188-2492 (imprimé)

1200-5320 (numérique)

Découvrir la revue

Citer ce document

Zucker, L. (1992). BIODEGRADABILITY: FLOATING ON THE SURFACE OF

CULTURE. Surfaces, 2. https://doi.org/10.7202/1065234ar
Résumé de l'article

Une étude de l'oeuvre de Charlotte Salomon présentée comme un exemple de pratique révolutionnaire et féministe dans la poétique.
Copyright @ Lisa Zucker, 1992

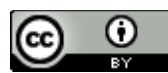

Ce document est protégé par la loi sur le droit d'auteur. L’utilisation des services d'Érudit (y compris la reproduction) est assujettie à sa politique d'utilisation que vous pouvez consulter en ligne.

https://apropos.erudit.org/fr/usagers/politique-dutilisation/ 
CONFERENCE PROCEEDINGS

"RETHINKING CULTURE"

BIODEGRADABILITY: FLOATING ON THE SURFACE OF CULTURE

Lisa Zucker

This paper was originally delivered at the conference Rethinking Culture held at the University of Montreal, April 3-5, 1992. The organizers would like to thank the following sponsors for their financial support:

Social Science Research Council of Canada

Faculty of Arts and Sciences, University of Montreal

Vice Rector for Teaching and Research, University of Montreal

Department of Comparative Literature, University of Montreal

Alitalia

ABSTRACT

A study of the work of Charlotte Salomon as an example of revolutionary feminist poetic practice. 


\section{RÉSUMÉ}

Une étude de l'oeuvre de Charlotte Salomon présentée comme un exemple de pratique révolutionnaire et féministe dans la poétique.

In an attempt to subvert the ascendence of the classic trope of Oedipal textuality, Kristeva promotes a revolutionary kind of writing, a reinscription of the dynamics of Klein's pre-Oedipal or "feminine" phase, re-named by Kristeva as the "semiotic."[1] The "feminine phase" constitutes for Klein a moment prior to the access of the pre-Oedipal child to language and thus to the symbolic structuring of the paternal name. And the semiotic is for Kristeva a metaphor for the unthinkability of the feminine moment which precedes and grounds signification. From this emerges the proposal of a new practice of writing, one which does not depend on the symbol of paternal reason or law, but rather on the metaphor of the infantile drives which pulsate rhythmically through the maternal body. This proposal is for a practice of writing as revolution and rhythm, a network of signs whose force is to be felt within and between the processes of signification, surviving parasitically as it were. Essential to this practice is the use of "bastard reasoning," Kristeva's instrument for thinking without the father, as a bastard, in the space between the "feminine" phase and the paternal phase of the symbolic. However, this is not reasoning in the classical sense, but a recuperation of the trope of the feminine as equivocal and undecidable, situating itself in a moment of femininity prior to symbolic law, while simultaneously practising a monumental theoretical discourse which in its very rigor effaces the poetic, musical position which conditions it.

The theoretical text which Kristeva elaborates is one which is paradoxically founded on pre-textuality and which thus attempts to be neither theoretical nor poetic but the "one and the other assuming the role of alternating stages in the process of signification." What is at work, then, is not a dialectical movement which synthesizes opposing poles, but a parasitic movement of decomposi- tion which binds the Oedipal and feminine phases while maintaining their heterogeneity, thereby displacing dialectical suppression and hierarchy.

By extension, the text is neither exclusively male, since the male principle could be described as being in a state of decomposition, nor is the text exclusively female since it does not occupy a static position in the preOedipal moment. Situated between the two, Kristeva's text affirms the 
feminine without succumbing to the delirium of the semiotic, and supports this affirmation by way of the cultural metaphor which identifies femininity with the poetic, musical register of language. Thus this project is founded on the negative force of the feminine metaphor, rather than on a simple appeal either to language as meaning or to the dissolution of sense in semiotic delirium. In seeming to acknowledge the ascendent order of the symbolic, Kristeva's project risks automutilation, inhabiting the moment of castration, but it does so specifically to put castration into play, by mobilizing within the symbolic moment the return of the repressed.

However, in reinscribing culture, that is, in using the cultural metaphor of the female hysteric and simultaneously attempting to transcend it, Kristeva could be said to recuperate by embodying the authority of the Oedipal region of meaning which she attempts so forcefully to impugn. Too frequently, we see Kristeva abandoning the marginal power of the parasite and taking an omniscient, masterful position in relation to the textual body which she is attempting to decompose. Kristeva spends more time theorizing than doing, performing. And understandably so, given the historical moment of her textual production. She is one of the first feminist philosophers to provide a methodology to other feminists for the achievement of revolutionary poetic practice. However it is the status of the constative explanation which is in question. In directing the brunt of her monumental project toward explanations of the way in which play can serve ideology, Kristeva reinforces the distinction between ideology and play, and tends to ideologize perhaps more than she plays, recommending "a signifying practice with a socio-historical function (and not simply auto-analysis, a substitute for the couch)." Too much play, for Kristeva, is non-productive preciosity. One may be sympathetic with her desire not to neglect ideological clarity, but we can see in other contemporary forms of feminist theory a mobilization of the playful or performative dimension of language for ideological purposes, playful texts which gesture metonymically toward the ideological constraints of their production in the manner which Kristeva ostensibly advocates.[2]

The suggestion of mastery implicit in Kristeva's appropriation of play recalls a similar move in the philosophy of Nietzsche, particularly in his use of prosopopoeia, that is, the placing of a mask or sign on death in order to translate it into fictional life. In this strategy, the figure of woman is associated with death and lack: she is the feminine mystery to be converted into a mirror image of the master's face and thus made comprehensible in masterful terms. In other words, she becomes a subordinate and subduable version of the master. However, the strategy is complicit with translating the master's helplessness into the appearance of power over the inaccessible, so that he takes on the traditionally feminine position as signifier. We can thus refer to a double set of maskings: the feminine as the mirror image of masculinity and masculinity as the mirror image of complete control or mastery. Furthermore, these masks must be projected without acknowledgment. Paradoxically, the master must be without a sense of being without perfect mastery, thereby multiplying the number of "withouts" as 
versions of the lack that was originally deemed feminine. Ironically, Nietzsche becomes by his own description a proliferating feminine sign, rendering himself eternally "without" a recognition of the series "withoutwithout-without" which parasitically reproduces itself to infinity.

This then is the point of decomposition of masterful texts, the point at which the authorial master no longer signifies or controls signification but becomes a proliferating process of signification -- the metaphysical subject having become what it always was: a pluralized, proliferant organism, the collective displacement and amnesia which forms a culture. It is the potential point of feminist deflection of masterful dialectic. Instead of confining the text to a system of masks or signs circulating around the binary opposition masculine-feminine and privileging masterful containment, an unlimited ironic multiplication of masks or points of view could work to avoid the fictional presence-to-itself which we have long come to associate with realism. Speaking through such a proliferation might help us to decompose identifiable origins or vanishing points of mastery long associated with the Grand Tradition.

Derrida's most recent term for this process of decomposition is biodegradability, a double binding figure used to designate "the worst but also the best that one could wish for a piece of writing." As Derrida notes, the term is often spoken of artificial industrial products and in particular of the artificial synthesis between the product and the parasites which decompose it. As such it becomes a flexible trope for a certain symbiotic relationship which exceeds the classical opposition between nature and culture. When a piece of writing is biodegradable, according to Derrida, it is "on the side of life, assimilated, thanks to bacteria, by a culture that it nourishes, enriches, irrigates, even fecundates but on the condition that it lose its identity, its figure, or its singular signature, its proper name." Biodegradability is conditioned by impropriety, by the unnatural graft which binds the product to its structural ruin and which lends a marginal status to its circulation.[3] Biodegradability risks and even thrives on discursive contamination yet is not easily assimilated to the homogenous compost heap of a natural language or culture. It floats on the surface of culture in plain sight, a small piece of pollution like many other waste products whose ubiquitous persistence challenge the promise of canonical permanence. Like a supplementary mask or face ("figure"), biodegradability reconfigures the face of a culture but does so in the process of disfiguring or defacing both itself and its culture.

What has been rigorously masked in the history of realism in art is the ideological character of artistic activity occurring within specific conditions of production and consumption. Nineteenth century realism was dedicated to the assignment of sexual roles in relation to the management of the desiring gaze of the patriarchal bourgeois consumer. Realism presented the illusion that total controlling knowledge of the feminine as Other is possible 
through representation, denying the complicity of artistic production with specific economic and psychic fictions generated in the social context. For this reason, the paradigmatic gender of the artist accepted into the art institution has traditionally been masculine. The feminine, on the other hand, has always been the paradigmatic visual object, presented for example in pre-Raphaelite painting as a passive still life, a bodily presence and vocal absence, her gaze vacant, frozen, or lowered, and thus recuperable as a commodity fetish, a signifier of property subjected and appropriated within the larger representational economy of capitalist consumption. Alternately, she is inscribed as the binary opposite of this image, a threatening figure of the Medusa who may be fragmented, dismembered, fetishized but above all silenced under the active, controlling gaze of the viewer assumed to be masculine. In the psychic economy of scopophilia, the masculine viewer purchases the pleasure of negotiating anxieties which circulate around the prospect of the feminine as threatening Other. However, such fetishism is still inscribed within the limits of the realist frame, a structure which naturalizes or deflects a recognition of the underlying mechanisms generating its differential and degrading sexual code. The realist frame encourages relative passivity even on the part of the fantasizing viewer who is thereby able to transform and dominate complex gender relations at his leisure. Thus realism frames a regional gaze dictated by the overseeing institutional gaze, whose shaping ideological impulse is organized around the image of woman as property, distributing that image as a socio-psychic product of oppression. [4]

The framing gaze of realism is thus aberrant: a cultural overdetermination of scopophilia. Such framing only appears to be natural, masking the viewer's coercion into a passive identification with fictional worlds reflecting oppressive hegemonies of class, sexism, and heterosexism. However, if this is the case, it could prove fruitful to call attention to realism's aberrant masks or frames, multiplying those masks in an attempt to mark the theatricality of representation and thus to engage the reader or viewer in active participation in the production of meaning. Rather than passively rereading the ideologically sanctioned codes of cultural consumption, the spectator would be transformed into an agent of cultural production actively engaged in questioning the underlying forces which shape art's reflection of contemporary social reality. Strategies for the generation of such active reading would include the erosion and fragmentation of traditional structures formerly dedicated to the production of a totalizable, masterful viewpoint. In place of a single, restful vantage point could be multiple points of view, complex seeing, and complex multilayered discourse, interdisciplinary montage combining a variety of genres, discontinuous narrative, a refusal of easy identification with heroes or heroines, a mingling of high and low styles and of different registers -- comedy, tragedy, song, image, sound, film -- all in an effort to displace or alienate the spectator from an easy visual totalization of gender or genre, focusing not on a single meaning or sensory perception but on the play of contradictions leading to the interrogation of meaning and opening the possibility of action. Such acts of subversion might recall the work of Bertolt Brecht in the 1930's. 
It would be crucial for revolutionary feminist texts not to ignore the overdetermined images of the feminine entrenched in patriarchy as a conventional social formation, but rather to gesture toward the political reasons for their strategic use, and to begin to reconfigure their use in politicized modes. Those archaic signs would be repeated and inhabited by feminist texts, attempting to complicate their consumption in a variety of frames intended to be politically disturbing, disrupting the conventional relations of sexuality in ideology. Such a critique, achieving its force through the performative mode of discourse, would be able to bypass the problem of criticizing theory from a position exclusively within theory and of appearing to grant excessive authority to the representations which it impugns. The traditional representation of the feminine as bodily presence and vocal absence would be exploded in a proliferation of voices speaking through the text, a Bakhtinian carnival whose discursive multiplicity would enact rather than describe the emancipation of the feminine sign, maintaining the ideological praxis advocated by Kristeva but avoiding the dialectical recuperation which occurs when the play of theory is given overt limits.

It would be in terms of such a reconfiguration of culture that we could locate the German expressionist autobiography of Charlotte Salomon. Charlotte Salomon was obliged to grow up functioning as a Jew within the dominant discursive régime of Hitler's "Jewish question" and the approach of its "Final Solution"; Salomon's discursive solution to this solution was to go underground in the south of France in 1939-42, and to locate herself within a massive autobiographical series of palimpsests entitled, in the original German, Leben oder Theater: Ein Singspiel which has been translated as Life or Theater: A Musical Comedy. This is a narrative series of 750 numbered water color gouaches (a dense form of waterpaint); an autobiography which is somehow also deemed theatrical, generating its writer as one theatrical character among others described in the third person. Taped onto each of the first 250 gouaches is a tracing paper painted with autobiographical commentary, additional sketches, directions for musical orchestration, and/or Nietzschean digressions, so that the body of the underlying gouache appears through the mask of writing with which it is decomposed. Significantly, the mask places into question the hierarchical relation between base and super- structure, and displaces the hierarchical privileging of a single bodily presence or vocal presence, demonstrating this feminist artist's sensitivity to the politics of the masterful gaze and of feminine muteness. Seeing and hearing are above all dramatized in this work which presents its authoress as a theatrical character described in the third person, in company with other characters who frequently appropriate the dialogue to produce a disquietingly heterogeneous text. In addition, there are long sequences depicting the theory of a Nietzschean master whose opus-in-progress is entitled significantly, Orpheus, or the Way to a Death Mask -- using as its epigraph a quote attributed to Nietzsche, "Learn to sing, O my soul." Yet the authority of the Nietzschean master and presumably of his Schopenhauerian theory of music is ironically undercut throughout the text, and from the very opening moment of his theatrical entrance, baldly accompanied by the Song of the Toreador from Carmen. It 
would not be in my interest to reconstitute the corpus of the text for review but I would like to offer several exemplary fragments.[5]

The first painting depicts Salomon's parents before she was born and is simultaneously implicated in the genealogy of the text. As such, it stresses the weakness of the image -- one which looks almost like graffiti, whose meanings are not totally definable by a dominating culture. According to narration elsewhere, we know that Albert is a military doctor specializing in gastric medicine for the Fatherland in the first world war, and here Franciska appears as a figure of assist, whose zigzagging hospital itinerary is traced and reduced to a flimsy line of discourse on the tracing paper, which reads: "She became a very efficient ward and operating nurse. There was one young surgeon whom she particularly enjoyed assisting. Since he had the sniffles, she had to wipe his nose during the operation. After the operation they parted, and Franciska made her rounds. But then they met again and had a little chat" $(L T, l l)$.

A close examination of the scene draws us to see that Franciska functions as an assist not to a gastric operation but to a castration. Through an arguably comic accident, the meaning of Albert's labor has been misinterpreted or dislocated, and this misinterpretation may be taken as a mischievous reference to the feminine author as the sign of error or accident. And the figure of Franciska assists at a scene which bathetically reduces the mourning which is traditionally inscribed within the scenario of castration to a set of sniffles. Castration is both invoked and deflected as a patrineal construct assisted by the sign of the feminine which is also the accidental force which can disrupt its coherence. Castration may also be metonymically associated with the diagonal red line which separates two narrative sequences which are painted onto the same page. As separation or differentiation, castration is tantamount to writing, and it is the red line of writing or narrative division which appears accidentally to amputate the leg of the patient. Even the genitals are not depicted realistically, but rather as a doubled or V-shaped sign of cleavage.

The V-shaped sign of cleavage is picked up in another narrative series of scenes in which Daberlohn, the Nietzschean theorist, rejected by a woman whom he calls the Madonna, rationalizes by meditating on the narcissistic nature of love. "So actually I only love myself in her, and when I look deep, deep into her eyes, all I see there is the reflection of my own face. Isn't this a sign that, whenever we believe we love each other, we are merely our own subject and object?" ( $L T, 274)$. In an attempt to embody the feminine other, that is, to deny or be without a sense of her difference, the Nietzschean theorist embodies the contradiction of subject and object, without a sense of being without universal knowledge, ironically producing fissures or gaps of ignorance which multiply to infinity. Finally, he is left sitting in a red pool, 
saying, "We should, as the creator of self-reflection, deny it. It limps, it has a devil's hoof" $(L T, 276)$. Yet denial merely perpetuates the problem, which the author allegorizes by painting him into the very cleavage which he describes.

The building up of a coherent image from the juxtaposition of lines which in themselves are weak, is called sfumato, and usually occurs within the frame of a single painting, as in French impressionism. Charlotte inverts this technique, expanding the reference between lines to reference between lines in different paintings, such as that of the V-shaped sign of castration. In that sense, the buildup might rather be described as a breakdown. Elsewhere, Charlotte refers to such a technique as that of the tri-colored line, claiming that it is built up slowly and with much deliberation, producing not expressionism but "the expression of the expression," not a coherent sign in itself but the process of signification, eternally open to misreading $(L T, 346)$. The line is flimsy and misleading, providing a link with an excess of other contexts. What is built up is the allegory of the breakdown of the sign.

In the autobiographical narrative, Charlotte's parents marry, and Franciska's role becomes more subordinate than it already was. As a mere commodity fetish in a German bourgeois household, she is pre-empted from being of any use in her own home. Even the raising of the child Charlotte is left primarily to a nurse. Franciska's husband ignores her bodily presence, deflecting his attentions instead to a book of the body, an anatomy atlas, leaving Franciska to read Nietzsche, or alternately to meditate on her own eviscerated life in a cinematic series of repetitions, and on the trait which has afflicted the entire female side of the family, the predisposition to suicide and the artistic sensibility which has seemed to accompany it.

The text of Nietzsche which Franciska reads is Zarathustra's parable of the lion, the camel, and the child, a tale of metamorphosis which achieves for the Overman the power of the child only through continual self-abnegation. [6] As in the description in the Genealogy of Morals in which the master's helplessness must be translated into the appearance of power over the inaccessible, such metamorphosis requires that the Overman take on the sign of the weakness of the signifier, here symbolized in the figure of the child. In other words, the mask or sign of mastery is imperatively inserted, in advance and without acknowledgment, as a translation of the helplessness of the master: he must "become" the signifier of mastery before he can "become" the signified master. Paradoxically, the master is reified in his repressed inscription of himself as masterful, but this self-imposed mask can progressively be erased as a mere signifier and inscribed a second time as a signified or "real" mastery -- again a movement of figuration on figuration, which ensnares the master as he zigzags between figuration and erasure, embodying the contradiction which he attempts to hide. In other words the radical fissure between signifier and signified has moved to the 
center of (the form of) masterful subjectivity. The master's being has mediated itself with linguistic nonbeing and simultaneously repressed the knowledge of that mediation in a senseless zigzagging between signifier and signified, a self-imposed mechanism which is the double of slavery even as it strives for mastery.

The slave is implicated in the mirror image of this dialectic. In the Genealogy of Morals, the slave, in his ressentiment, turns to himself as to an exchange value, and begins to "exist" insofar as his automutilation, his convergence on his own pain as an affect, has been transformed into the cultivation of "cleverness."[7] That is, the affects of suffering has been translated into the language of those affects. In this sense, the slave's "condition of existence" is the effect of exchange or translation; his cause is the effect of affects, at least according to the program of the ascetic priest. In this way, the slave becomes the perfect paranoiac who "understands how to keep silent, how not to forget, how to wait, how to be provisionally selfdeprecating and humble" (GM, 38-39). Having "come to terms" through linguistic displacement, he has learned to translate his suffering into guilt, to inflate it economically as the effect of other affects, and thus to internalize greater and greater amounts of it, deadened as it is by its intertwining with the terminology of sin. Ressentiment has all but disappeared, or rather is deeply repressed for "it has always bloomed, in hidden places, like the violet, though with a different odor" (GM, 73). In its place is suffering separated from its meaning by translation.

To treat cause as the effect of affects by turning the slave back upon his own instincts as guilty affects to be translated, and then displacing his pain with "more savage affects" is to create an "orgy of feeling" insofar as the inversion scatters and multiplies the properties of the subject. Cause and effect are intertwined by means of the translation of cause so as to make the terms cause and effect divisible equivalents capable of substitution, reversal, multiplication, and inflation. The slave is encouraged to will the repression and misinterpretation of cause as affect, even to enjoy it, and thus seems to become the entrepreneur of his own affects. The results are feminized by Nietzsche in terms of pregnancy: The slave's "womb" begins to inflate with the proliferation of internalized and translated affects: "The entire inner world, originally as thin as if it were stretched between two membranes, expanded and extended itself, acquired depth, breadth, and height, in the same measure as outward discharge was inhibited"(GM, 84-85).

Since the slave has managed to figure himself as the capitalist of his own affects, his affects can appear to be interchangeable with those of his masters, for meaning has lost its measure in a world of equivalency. If the slave now actively labors to dislocate a force from its affects, it is because force can thus be made to turn against itself and be translated or 
intertwined with practically anything else to become "totally indefinable." The externalization and capitalization of force can appear to make master and slave, or even pleasure and pain, interchangeable. Since the identity of the slave consists of a collection of affects, these may translate equally well into the affects of mastery. In fact, insofar as such affects manage to proliferate and "swamp" the coherence of masterful texts, they configure the mastery of mastery.

The Nietzschean inversion of guilt as debt so that it may be reinvested in a "pregnant" proliferation of affects seems to be at work in the painting of Franciska whose caption reads, "Am I at fault for my sister's death?" (LT, 126) The question of who is at fault depends on the German word for fault -Schuld -- which also means debt, translating the sentence as, "Am I indebted to my sister's death?" Suicide could be seen as the most extreme attempt to place a mask on the gap or fault of death, a symbolic act divided (at fault, as it were) between submission and transgression in relation to paternal law. On the one hand, it tries to appropriate and thus negate the power of God the Father. On the other hand, it acknowledges paternal power in the very desire to have it. Yet suicide leaves survivors with the debt of existential uncertainty, and perpetrates the chain of automutilative inversions and displacements which perpetrate the problem.

Charlotte's work reiterates the slavish, automutilative artistic chain of transmissions which runs through the female side of the family but which in her case does not end in suicide, a final solution which above all would put a stop to the poetic act of outfacing death. Instead, like Nietzsche's slave, she is the perfect paranoiac who "understands how to keep silent, how not to forget, how to wait, how to be provisionally self-deprecating and humble." Her paintings are hermetic, not given to easy expression or inter- pretation, and above all dedicated to the disfiguration of death. In the painting in which Franciska examines her own Schuld, her face appears framed as a mask between two masks in profile looking inward.

Franciska pursues to its extreme the question of negotiating the debt of her sister's death, and commits suicide, but before she does so, she leaves an unheard-of promise or debt for her daughter -- a letter describing what heaven is like. The suicide occurs as a leap from the window which is also the site where the letter is promised to return $(L T, 30)$. And the survivor's act of masking includes mutilating and representation of the act, throwing the window out of the window, and painting a foot in the extreme foreground which inverts the act of suicide into an act of return. Writing or painting produces the potential return of the maternal letter. In contrast to a depiction of the artist as masterful Other Who Knows and fills the image with meaning, this artist appears only in the redoubling of the frame as mask, producing not the image but the problem and process of interpretation in an unresolved, self-questioning work hovering in the 
intersection between life and theater as between the mother's body and the daughter's text.

Yet the signs of castration and of feminine weakness are signs which are both marked and masked by an text which does not allow itself to be totalized by a psychoanalytic reading. In a series of painting of Charlotte's Nietzschean mentor, he appears as a series of reduplicated heads, a proliferation of the metaphysical category of mind or the mental subject like the "pregnant" proliferation of the slave in Nietzsche. In these paintings, the master describes psychiatry as yet another mimetic, self-reflective act of placing a mask of death, an act of domination incurring debt as a multiplicity of gaps or deficiencies: "We see all those psychoanalysts around the conference table, deliberating the deficiencies of the contemporary human soul, exploring the cultures of the remotest peoples to rediscover primeval man untouched by European culture. In many cases I would call that an attempt to establish a new European culture, that of psychoanalysis: instead of taking a burden off the tormented soul, adding a greater burden to it. Imitating other peoples or oneself can only result in a culture of apes and parrots" $(L T, 406-08)$ We can see once more that he both describes and embodies the problem of repression and irrepressible reduplication -- a version of the transference affect which psychoanalysis has never been able to master.

The opera "Der Freischütz" which is written in as an orchestration for a number of the paintings referring to Franciska's suicide is a musical piece in which the heroine opens a box and discovers death. But the death sentence which Charlotte adopts is the displaced line of feminine weakness which as she notes has something to do with her mother and with the feminine, artistic line of her family. It is not a sentence which speaks directly but one which emerges as suggestion from out of the fault or interstice between scenes, out of the pressure exerted by the sudden collapse of the layers of the tri-colored line, producing an unexpected intersection and administering a shock of recognition. If writing suggests the sign of castration as separation, one might deflect it by succumbing to it in multiply decentered modes of automutilation, with no overt reference to psychoanalytic motivation. The V-shaped sign of the master may be divided multiple times to produce the automutilation and multiple branching of text and voice, dislocating meaning at one's peril, or perhaps in the service of a peculiar, musical comedy. So, in Life or Theater, death seems to be confused with the engineering of accidents, decapitations, and disrupted meanings. The work seems to succeed by virtue of its internal weakness or failure to contain signification.

The very first painting of the project says, "One November day Charlotte left her parents home and threw herself into the water." (LT, 7). The date 1913 identifies the suicidal drowning of Franciska's sister, also named Charlotte, who appears to us in another painting as a floating body, her face covered by 
water which recovers itself at the discursive level as watercolor wash (LT, 125). In turn both of these paintings resonate with Charlotte the painter, who throws herself into her medium and learns to float. The maternal death sentence is that which derives its force from the very gravity of death, converting that gravity into a strange lightness, and by extension, levity. In a final painting, we see Charlotte's stepmother, a famous opera singer who enters the household to displace Franciska, and figures in the ha-ha-ha of her singing exercise the way in which the singularity of the voice may break apart, collapsing its operatic grandeur into traces of helpless, intertextual laughter $(L T, 64)$.

Life or Theater: A Musical Comedy. The project works a new irony of gesture which speaks as a regional voice within the horizon of revolutionary poetic practice advocated by Kristeva. Charlotte's text inscribes not the fulbodied laughter of the ecstatic, desiring mother, but a hermetic laughter invested nevertheless with ghostly jouissance. According to Kristeva, it is: "a kind of laughter whose only explosions are those of language. The pleasure obtained from the lifting of inhibitions is immediately invested in the production of the new. Every practice which produces something new (a new device) is a practice of laughter: it obeys laughter's logic and provides the subject with laughter's advantages. When practice is not laughter, there is nothing new: where there is nothing new, practice cannot be provoking: it is at best a repeated, empty act. The novelty of a practice (that of the text or any practice) indicates the jouissance invested therein and this quality of newness is the equivalent of the laughter it conceals. Beyond merely laughable phenomena and through prohibition, [the] text bears this message for social practice" $(R, 225)$.

\section{Lisa Zucker}

Université de Montréal

Surface Page d'Acceuil/Home Page

\section{Biographical Notes}

January 1939 Charlotte comes to l'Ermitage in Villefranche under the patronage of Ottilie Moore and paints 
March 1939 Alexander Nagler arrives at l'Ermitage with his sister-in-law Annie and his brother Hans to receive refuge, becomes Moore's lover; break-ups and returns

March 1940 Charlotte and grandparents move to Nice; grandmother commits suicide, half dragging Charlotte out the window with her; three months of mental illness

June 22-July 22 Charlotte and grandfather are incarcerated at the labor camp at Gurs, then released due to grandfather's age; Annie Nagler is there at the same time

August 1940 Charlotte continues to paint $L T$ under Dr. Moridis' advice; Alexander nurses her health; letters to parents

September 27, 1941 Mrs. Moore leaves l'Ermitage for America with 10 refugees

October 1940 Vichy laws

Autumn 1941 Charlotte paints alone for 2-3 months in a hotel at St. Jean

Early 1942 Charlotte smuggles Alexander to a clinic for his ulcer operation, then hides out with him for a week at the Moridis, for post-ope- rative medical care, then returns to the children; Charlotte paints the operation?

June, 1942 Jews of France's occupied zone become societally inscribed with yellow stars; radical university students attempt to disseminate this inscription by distributing yellow stars to non-Jews

August 1942 Submission of $L T$ to Dr. Moridis in Villefranche

November 1942 Deportations begin in south of France

February 1943 Grandfather dies in Nice

May 1943 Marriage "in quotes" (Charlotte's term); Alexander's application for a marriage licence is turned down because his identity card is not stamped "Jew" and an interracial mariage to a Jewess is prohibited; he blurts out his racial identity and is granted the licence but his false identity paper is confiscated; the couple accepts Dr. Moridis' offer of his apartment in Nice as a hiding place but presently return to Villefranche and refugee children

September 21, 1943 Arrest of the entire household at l'Ermitage and deportation through Lyon and Drancy to Auschwitz; Charlotte is four months pregnant; the date of her murder is not known.

[1]See Julia Kristeva, La révolution du langage poétique. L'avant-garde à la fin du dix-neuvième siècle: Lautréamont et Mallarmé (Paris: Seuil, 1974); translated as Revolution in Poetic Language by Margaret Waller (New Yor: Columbia University Press, 1984); hereafter referred to as $R$. See especially the section entitled "Practice." 
[2]See, for example, Jane Gallop, The Daughter's Seduction: Feminism and Psychoanalysis (Ithaca: Cornell University press, 1982).

[3]Jacques Derrida, "Biodegradables: Seven Diary Fragments," trans. Peggy Kamuf, Special Issue "On Jacques Derrida's 'Paul de Man's War," Critical Inquiry 15, Summer 1989: 812-73.

[4]See Griselda Pollock, Vision and Difference: Femininity, Feminism and the Histories of Art (London and New York: Routledge, 1988).

[5]A large portion of the Salomon collection may be located in Leben oder Theater? Ein autobiographisches Singspiel in 769 Bildern (Cologne: Kiepenheuer \& Witsch, 1981), translated as Charlotte: Life or Theater? An Autobiographical Play by Charlote Salomon, tr. Leila Vennewitz (New York: Viking Press \& Gary Schwartz, 1981). Since the pagination in these two texts is exactly the same, they will be collectively referred to hereafter as $L T$. Since Vennewitz's translations do not appear to have resonated with certain Nietzschean quotations and thematics at work in the text, I have substituted my own translations in places. Further sources include an earlier, smaller selection which appeared as Charlotte Salomon, Ein Tagebuch in Bildern, 1917-1943 (Hamburg: Rowohlt, 1963), translated as Charlotte: A Diary in Pictures, tr. Ralph Manheim (New York: Harcourt, 1963). Cf. also the exhibition catalogue of Christine Fischer-Defoy, Charlotte Salomon -- Leben oder Theater? (Berlin: Das Arsenal, 1986). I would like to thank Judith Belinfante, Director of the Joods Historisch Museum, Amsterdam, for allowing me to use the Charlotte Salomon Archive and for reproduction permissions. I am also grateful to Paula Lindberg-Salomon for kind hospitality and intriguing anecdotes. Finally, I would like to extend my thanks to the Comité d'attribution des fonds internes de recherche (CAFIR) and to the Fonds pour la formation de chercheurs et l'aide à la recherche (FCAR) for the financial support which made research for this essay possible.

[6]Friedrich Nietzsche, Thus Spake Zarathustra, in The Portable Nietzsche, translated by Walter Kaufman (New York: Viking Press, 1954): 139ff.

[7]See Friedrich Nietzsche, On the Genealogy of Morals, translated by Walter Kaufman (New York: Vintage, 1969), hereafter referred to as GM. 